\title{
BRAZIL'S INTERNATIONAL COOPERATION IN SCIENCE, TECHNOLOGY, AND INNOVATION IN THE CONTEXT OF THE COVID-19 PANDEMIC
}

\author{
Aline Chianca Dantas \\ Júlia Mascarello \\ Nanahira de Rabelo e Sant'Anna ${ }^{3}$
}

\begin{abstract}
SINOPSE
Este artigo pretende discutir a cooperação internacional do Brasil em ciência, tecnologia e inovação (CT\&l) no contexto da pandemia da Covid-19 por meio da análise das iniciativas bilaterais conduzidas pelo país de janeiro a julho de 2020. A pesquisa foi baseada principalmente na investigação de websites dos principais atores brasileiros de CT\&l no nível do Poder Executivo, considerando os ministérios e suas instituições relacionadas. Para desenvolver esta pesquisa, primeiramente apresenta-se a relação entre Covid-19 e CT\&I. Em segundo lugar, analisam-se os argumentos sobre a cooperação internacional em CT\&l inserida no cenário atual da pandemia. Em terceiro lugar, apresentam-se dados sobre CT\&I do Brasil e uma discussão sobre as suas atividades na cooperação internacional em CT\&l. 0 quarto e último ponto consiste no desenvolvimento de um quadro das iniciativas de cooperação internacional brasileira em CT\&I coletadas, seguido de uma reflexão envolvendo especialmente atores e áreas. A análise mostra que o Brasil está notoriamente cooperando em distintas áreas de CT\&l, muitas delas vinculadas aos interesses estratégicos do país; contudo, há um destaque para iniciativas na área de saúde e relacionadas à Covid-19, em virtude do contexto analisado. Em relação aos países parceiros, percebe-se que a maior parte das interações se dá com países desenvolvidos, apesar de relações com países em desenvolvimento também serem observadas, especialmente a destacada cooperação com a Índia.
\end{abstract}

Palavras-chave: cooperação internacional; ciência, tecnologia e inovação; Brasil; Covid-19.

\begin{abstract}
This article intends to discuss Brazil's international cooperation in science, technology, and innovation (ST\&l) in the context of the Covid-19 pandemic through the analysis of the bilateral initiatives conducted by the country from January to July 2020. The research was based mainly on an investigation in websites of key Brazilian ST\&I actors from the Executive level, considering Ministries and their related institutions. In order to develop this research, firstly, we presented the relation between Covid-19 and ST\&I. Secondly, we analyzed the arguments about international cooperation in ST\&I within the current pandemic scenario. Thirdly, we presented data about ST\&I in Brazil and a discussion about its activities within ST\&l international cooperation. The fourth and last point consisted of developing a framework about the collected initiatives of Brazilian international cooperation in ST\&l, followed by a reflection especially involving actors and areas. Our analysis showed that Brazil is notoriously cooperating in distinct areas of ST\&I, many of them related to the country's strategic interests; however, there is a highlight to initiatives in the health area and connected to Covid-19, due to the analyzed context. In relation to partner countries, it is noticed that most
\end{abstract}

\footnotetext{
1. PhD in International Relations at the University of Brasilia (IREL/UnB); professor of International Relations at Paulista University (UNIP), Brasilia; member of the CNPq Research Group International Relations and Science, Technology and Innovation (RICTI).E-mail: <alinechiancadantas@gmail.com>.

2. PhD candidate in the Postgraduate Program in International Relations at the Federal University of Santa Catarina (PPGRI-UFSC); member of the CNPq Research Group International Relations and Science, Technology and Innovation (RICTI). The researcher would like to thank the Capes Foundation for the financial support (PhD grant) without which the research that resulted in this article could not have been carried out. E-mail: <juliamascarello@hotmail.com>.
}

3. PhD in Development, Society and International Cooperation at the University of Brasilia (PPGDSCI/CEAM/UnB). Science and Technology Analyst of the Brazilian Ministry of Science, Technology and Innovation (MCTI).E-mail: <nanahira.rabelo@gmail.com>. 
of the interactions are carried out with developed countries, although relations with developing countries are also observed, especially the prominent cooperation with India.

Keywords: international cooperation; science, technology and innovation; Brazil; Covid-19.

JEL: 019; 038.

Artigo recebido em 31/7/2020 e aprovado em 7/8/2020.

DOI: http://dx.doi.org/10.38116/bepi27art4

\section{INTRODUCTION}

The new coronavirus was first identified in Wuhan, China, and since then the virus is spreading at a high speed (Haverty, Palmer and Kelly, 2020). Brazil, ${ }^{4}$ for instance, is the second most affected country in number of cases, being only below the United States 5 (Johns Hopkins, s.d.). Regarding this scenario, Covid-19 is a world issue and its solution is clearly related to science, technology, and innovation (ST\&I), mainly with the development of an effective vaccine. Additionally, international cooperation is an important instrument to accelerate researches and discoveries.

In this sense, this article aims to analyze Brazil's international cooperation in ST\&I in the context of the Covid-19 pandemic, observing the bilateral initiatives of international cooperation involving Brazil's main ST\&I actors from January until July $2020 .^{6}$

We stress the relevance of this work in many ways. First of all, research in social sciences during the Covid-19 period matter and are quite necessary because they can bring big picture analyses (Wen et al., 2020), which is exactly what we intend to develop in this study. Furthermore, there are no broad investigations in the literature about Brazilian initiatives of ST\&I international cooperation, especially in the context of Covid-19, which is fundamental for understanding the key partners, issues, types of relations, and the connection with our main goals on ST\&I. However, it is necessary to highlight that studies and conferences about Brazilian ST\&I in the context of the Covid-19 can be found (De Negri and Koeller, 2020; De Negri, Máximo and Gomes, 2020), and they are also important in order to discuss the framework of ST\&I within Brazil and the possibilities for international cooperation.

In order to achieve the goal of this article, we need to make clear that we are analyzing only Brazilian international cooperation that involves ST\&I which is different from and does not involve technical cooperation or other initiatives of international development cooperation. In this sense, we considered the initiatives that were related to shared development of knowledge, through researches, creation, production or application of technology, or yet the creation of new products using previous technologies or scientific knowledge. This operational definition is based on the concept of science, technology and innovation argued by Skolnikoff (1993). Thus, relationships linked to donations, purchasing of technologies, training of human resources, and so on were not included in this study. Also, the authors decided to consider international cooperation initiatives the following

4. In Brazil, the first case was reported on February 25th, 2020 (Johns Hopkins, 2020). However, this study considers a period of analysis from January until July 2020, since the virus was already spreading around the world. The first case in China was reported on November 17th, 2019 (Davidson, 2020).

5. In order to observe detailed data about the coronavirus spread in the world the website of Johns Hopkins University can be analyzed. Available at: <https://coronavirus.jhu.edu/data/new-cases>

6. The research was conducted until July, although the results generally showed initiatives of cooperation up to June. 
ones: negotiations, meetings, missions, work plans, bilateral instruments such as letters of intent, memorandum of understanding, public calls, notices, and cooperation agreements.

After clarifying the object of analysis of this article, we should explain the methodology of the study, which was based on a broad search on the websites of the main Brazilian ST\&I actors within the Executive Branch, considering the ministries and their related entities and institutions. We used the terms international cooperation, cooperation, international, science, and technology as well as searched at existing international cooperation or international relations tabs, and at the tab "News". It must be stated that since we are only considering the context of the pandemic, the information considered for our research were those dated from January to July.

The choice of the ST\&I actors was conducted using the document of the Ministry of Science, Technology and Innovation (MCTI) named National Strategy of Science, Technology, and Innovation (ENCTI) 2016-2022 (Brasil, 2016), which presents the main ST\&I actors and mentions the relevance of the Executive and Legislative as well as society participants (entities of sectorial representation, involving entrepreneurs, workers and researchers), and especially a document from the Center of Management and Strategic Studies, ${ }^{8}$ which shows the main ministries involved in ST\&I and the institutions linked to them. In this sense, we decided to focus on the Executive Branch, including the federal level with the Ministries, its entities and institutions, and the subnational level through the State Research Foundations (FAPs). Thus, we analyzed the following Ministries and its institutions: MCTI, Ministry of Environment (MMA), Ministry of Defense (MD), Ministry of Education (MEC), Ministry of Health (MS), Ministry of Economy (ME), Ministry of Mines and Energy (MME) and Ministry of Agriculture, Livestock and Food Supply (MAPA). We also included in this research the Brazilian Company of Research and Industrial Innovation (Embrapii), and data related to bilateral agreements from the website Concordia of the Ministry of Foreign Affairs (MRE). ${ }^{9}$

Considering the huge size of this research, we did not include in our study private actors, universities ${ }^{10}$ and federal education institutions (IFs), which are certainly very important for the development of ST\&I in Brazil, since putting together all the fragmented information of these initiatives would demand much more time and resources. Besides, this research did not consider multilateral cooperation initiatives as well as cooperation with only domestic actors, although the authors are aware of their existence, and pointed out some notes about them in the last part of the article.

It is important to say that the researchers have also sent information requests to some specific ST\&I actors, namely MCTI, MS, MRE and the Oswaldo Cruz Foundation (Fiocruz), but, in the period that comprised this research, only received answers from Fiocruz. Considering the report provided by this specific actor, it was not possible to ensure that the cooperation initiatives related to the Covid-19 were already existing cooperation and were just reoriented towards the new topic or if they were created as a need of the Covid-19 pandemic. Also, the authors could not verify the report deeply because the material received did not provide key aspects of the initiatives such as the type of

7. The research focused more on analyzing the initiatives than verifying how they are being processed, nor did it seek to make comparisons with the previous period, so the impact of social distance, determined by federal normative instructions and state, district or municipal decrees or district laws, was not measured on "the capacity for international cooperation".

8. Available at: <https://www.cgee.org.br/documents/10195/734063/Mapa+CTI_177x118_19mai10_6585.pdf/6e1db9a5-0642-4a43-

9e9d-8a8cde1ee051?version=1.0 > .

9. Available at: <https://concordia.itamaraty.gov.br/>

10. The universities only appeared in the analysis when they are partners of other Brazilian institutions considered. 
instrument or date. In the case of FAPs, the authors requested the National Council of State Funding Agencies (CONFAP) information on initiatives related to Covid-19 by FAPs but received only a material containing national cooperation among Brazilian institutions, information that shows the importance of this type of initiative in terms of ST\&I and Covid-19 in Brazil. In this sense, the data collected about FAPs initiatives of cooperation followed the methodology aforementioned.

Considering these notes, the authors understand that at some point the analysis can be influenced by the availability of information from one Brazilian actor in comparison to others as well as to the most prominent partners of cooperation in ST\&I with Brazil in the considered context and time. Thus, the distinguished role of India and Fiocruz in our analysis can be related to this explanation.

All the information resulted in a database categorized in a table that included: name of the initiative, type of bilateral instrument, Brazilian actors, foreign actors, date, and areas mentioned in the cooperation initiatives. The cooperation initiatives were displayed in alphabetical order considering the Brazilian actors. This table resulted in the systematization of the predominant areas of Brazilian ST\&I cooperation, indicating the number of times that the area appeared and the partner country involved in each area. In the case of Covid-19 initiatives, even though it may include sub-topics such as research, treatments, vaccines, and others, the authors decided to allocate them all in a Covid-19 broad area, also departing from the understanding that all Covid-19 initiatives are, after all, related to solving the pandemic and then, related to health. At the same time, areas that involved health but were not related to the Covid-19 were considered simply as "health".

The article is divided into four parts, besides this introduction and the final remarks. First, we discuss the relation between Covid-19 and ST\&I. Second, we analyze the arguments about international cooperation in ST\&I within the current pandemic scenario. Third, we present data about ST\&I in Brazil and a discussion about its activities within ST\&I international cooperation. The fourth and last point involves the development of a frame about the collected initiatives of international cooperation in ST\&I and a discussion about the results.

Our analysis showed that Brazil is notoriously cooperating in distinct areas of ST\&I, many of them related to the country's strategic interests. However, there is a prominence of initiatives in the health area and connected to Covid-19 due to the analyzed context. Concerning the partner countries, it is noticed that most of the interactions involve developed countries, although there are relations with developing countries, especially the prominent cooperation with India.

\section{THE RELATION BETWEEN COVID-19 AND ST\&I: POSITIVE IMPACTS AND CHALLENGES}

To understand the whole picture in which Brazil is placed in terms of international cooperation in ST\&I during Covid-19 period, we should first mention briefly the history of ST\&I development and the possibilities of continued changes in the area, especially regarding the current context of the pandemic. After that, we will discuss the positive impacts ${ }^{11}$ and the challenges of the pandemic for ST\&I in the world.

11. Although we are facing a death disease with Covid-19, its effects promoted the rethinking of established practices in ST\&l, reinforcing discussions of free access and international cooperation. In this sense, we consider these points as positive impacts for ST\&l and they will be analyzed in this part of the article. 
Thus, considering the historical transformation of ST\&I throughout international politics - for instance, with the Second World War and the Cold War - we could also think about possible changes in ST\&I during and after the Covid-19 pandemic (Saraiva, Oliveira and Morejon, 2020) due to its huge dimension involving all countries around the world - developed and developing ones - and an expected solution related to scientific knowledge.

Regarding the historical transformation of ST\&I, Skolnikoff (1993, p. 4) reinforces that the "accelerated commitment of resources to research and development during and after World War II has transformed the relative haphazard climate of invention and scientific research of earlier centuries". It is also pertinent to highlight the changes fostered by the Cold War and the expectation of future developments on ST\&I, as follows:

the influence of technological change in the disintegration of communism in Eastern Europe and the Soviet Union is but one manifestation of a much larger story in which the results of science and technology have contributed to a profound evolution of the details and substance of national and international affairs. The effects are visible not only in the outcome of the communist experiment, but in the countless alterations in the relationships within and among nations and peoples. And that influence is likely to continue to be significant long into the future as the nations of the world remain strongly committed to supporting research and its products (Skolnikoff, 1993, p. 3).

Following this evolution on ST\&I promoted by specific historical events, the Covid-19 pandemic may also be considered as a possible breakthrough in ST\&I, and this is why the current literature is dedicated to discussing it. In this way, ST\&I is being observed not only through the perspective of costs, but especially as the main solution for the pandemic crisis (Chesbrough, 2020).

Based on that, as a positive impact of Covid-19, we can note the important dialogues about open science ${ }^{12}$ and innovation that could enable widespread experimentation and creation of business value, considering, for example, that some patents in large companies sometimes are not used or licensed (Chesbrough, 2020). Open science can still be an instrument of inclusion and promotion of equality among countries, especially considering that developing countries do not always have access to the latest research and brand-new technologies ${ }^{13}$ (Roehrl, Liu and Mukherjee, 2020). Yet, researchers can learn with previous investigations and go deeper in knowledge development, benefiting the world society, and moving beyond the barriers of intellectual property (Chesbrough, 2020). The great challenge in the promotion of open science and innovation is the coordination for open platforms to collect initiatives, data, and also transmit trust among researchers (Chesbrough, 2020).

Additionally, as another positive impact of Covid-19 in ST\&I, we should mention the important mobilization of scientists, diffusion of scientific information, and possibilities of international cooperation (Chesbrough, 2020). The pandemic enhanced the weight of science in order to guide public policies, although not all countries followed in a perfect way this movement (Young, 2020), and reinforced the necessity of creation and transference of scientific knowledge as a critical point for global economic integration and socio-economic welfare (Müller, Schmitz and Josten, 2020, p. 20).

12. "The idea behind Open Science is to allow scientific information, data and outputs to be more widely accessible (Open Access) and more reliably harnessed (Open Data) with the active engagement of all the stakeholders (Open to Society)". Available at: <https://en.unesco.org/ science-sustainable-future/open-science>.

13. It is important to mention that UNESCO is an important actor to improve open science discussions, as we can see with the Virtual Dialogue on Covid-19 and open science that occurred on 30 March 2020. Available at: <https://en.unesco.org/news/unesco-hosted-virtual-ministerialdialogue-covid-19-and-open-science>. 
A last positive aspect that we can highlight about ST\&I during Covid-19 is the glance for better integration and cooperation amid science, policy, and society (Roehrl, Liu and Mukherjee, 2020). Anyway, it is still necessary to stimulate policymakers, civil society, and the private sector to further collaborate with scientists in order to share scientific information (Müller, Schmitz and Josten, 2020, p. 20).

After the presentation of the good reflections of Covid-19 in ST\&I, we should also take a look at the challenges that the virus showed us regarding ST\&I. We can emphasize the political interests and interferences in knowledge sharing and international cooperation in ST\&I (Young, 2020) and also the possible limitation in the use of scientific evidence in policymaking within certain countries (Roehrl, Liu and Mukherjee, 2020). Yet, there is also the bad side of science competition considering the withholding of knowledge in order to protect its own reputation, data ownership, privacy, and intellectual property (Young, 2020). In this latter case, there is a known example of China's silencing of the first discoveries about Covid-19 disease, vetting publications by Chinese researchers, and censoring the mention of the virus' origin (Young, 2020).

Moreover, there is a discussion of whether access to a Covid-19 vaccine will be a public good or a private one and about the problem of science misleading narratives, for instance, using social media (Young, 2020). Another noticeable aspect is the adaptation of researches and projects conducted before Covid-19, considering a restricted movement in the direction of the main topic of the moment (Mallapaty, 2020). It is also relevant to regard the new challenge of Covid-19 for researchers with respect to field research, mobility, exchange, and available funding (Mallapaty, 2020). Last but not least, it is necessary to improve trust in science, especially outside Northern and Western Europe. Research conducted about this topic revealed that the level of trust in science in South America is much lower than in Europe, and in Central Africa the situation is still worse (Rabesandratana, 2020 apud Roehrl, Liu and Mukherjee, 2020). This evidence raises the question about Brazil's position in this scenario of science (dis)trust and scientific evidence-based policies, especially with all the political discussions around Covid-19 disease within the country.

Summing up, the scenario presented about ST\&I and Covid-19 shows ways for better development of ST\&I after the pandemic and the changes and discussions that are still in course. However, the improvement process of ST\&I is not easy or fast. It demands the involvement of the countries and certainly, competition and national interests will still be a challenge that researchers and societies will have to deal with.

\section{INTERNATIONAL COOPERATION IN ST\&I AND THE COVID-19 PANDEMIC}

After analyzing the role of ST\&I in international politics across time and how scientific and technological development relates to the Covid-19 pandemic, we must understand why international cooperation becomes important, especially in this scenario.

In general, considering a globalized world in which states are not self-sufficient but interdependent at some level (Keohane and Nye, 1998), international cooperation is necessary if states intend to develop their ST\&I capacities. In the literature, there are several reasons why States cooperate in ST\&I. Departing from a state-centered view, authors that share a more liberal view of cooperation explain that states may finance international cooperation in ST\&I for meeting policy goals, such as 
national security and foreign relations, or public goals as the production of scientific knowledge to promote economic growth (Wagner, 2006).

On the other hand, authors with a more realistic view explain that states may cooperate in ST\&I to improve their technological capacities and to be aware of their partners' ST\&I capacities and, as a result, to ensure their scientific-technological superiority (Krige and Kai-Henrik, 2006; Krige, 2014). At the same time, in the perspective of scientists, international cooperation occurs in order to share costs of ST\&I projects, to facilitate access to material resources, to share data, and to exchange ideas between scientists (Wagner, 2006).

More specifically, the scientific and technological development in health has its impacts in the global economy since besides solving global issues, it has been used as a way of achieving foreign policy interests and it is directly related to economic development, promotion of security and guaranteeing the stability of the world order (Brasil, 2018). As a result, international cooperation in health is necessary for countries that want to develop their capacities in the area as well as to prevent and find solutions for new diseases and epidemics, which can be a result of the current context of high displacement and mobility of people (Brasil, 2018).

In the case of a pandemic, which is considered a transnational threat that involves a public health issue and the recognition that its solutions are only found in science, it is expected that countries cooperate in order to face it and find the appropriate solutions by producing collective research and sharing knowledge and data. ${ }^{14}$ As a result of the need for global collective action, there is a tendency to regard international cooperation as an important and positive instrument. Moreover, despite multilateral mechanisms and the capabilities of international organizations created in previous disease scenarios, it is proved that these advances were not enough (Young, 2020). In this sense, the improvements in ST\&I already discussed and more possibilities of international cooperation are fundamental.

Based on that, since the World Health Organization (WHO) declaration on March 11 that characterized the Covid-19 disease as a pandemic, ${ }^{15}$ several international cooperation initiatives in ST\&I have been established among multiple actors (scientists, companies, states, International Organizations) to face the pandemic (Mascarello, 2020). At the same time, recent research (Fry et al., 2020) showed that when analyzing comparatively the cooperation among scientists in the context before and after the Covid-19 pandemic, it can be noticed a decrease in the number of joint publications. One of the reasons is that in a context in which scientists need to provide fast research results, there is a preference for working in smaller and known teams, involving fewer nations.

Furthermore, when analyzing the cooperative initiatives of multiple actors, it can be noticed that they involve mostly countries from the Global North in the areas of medicine and vaccines development, while Southern countries are involved mostly in initiatives of research collaboration, funded by the North, which denotes an asymmetrical relationship (Mascarello, 2020). The same happens in scientists' collaboration, which have increased among important countries such as China, and decreased the participation of other developing countries (Fry et al., 2020).

14. Available at: <https://en.unesco.org/news/unesco-hosted-virtual-ministerial-dialogue-covid-19-and-open-science>.

15. Available at: <https://www.who.int/dg/speeches/detail/who-director-general-s-opening-remarks-at-the-media-briefing-on-covid-19-11-may-2020>. 
Finally, even in a scenario of apparent cooperation, it should be considered the increase in rivalries among states due to the attempt of blaming each other and competing to be the first to develop a vaccine and surpass the economic crisis. As an example, there is the case of Taiwan, which had its inclusion in the World Health Organization (WHO) blocked by China, preventing the world from learning from Taiwanese successful examples dealing with Covid-19 (Young, 2020). Thus, with these considerations, we move on to the third part of this article to understand ST\&I in Brazil and how the Covid-19 scenario impacts on Brazil's international cooperation in this sphere.

\section{ST\&I IN BRAZIL AND INTERNATIONAL COOPERATION}

To analyze the scenario and the dynamics of Brazil's international cooperation in ST\&I, more specifically in the context of the Covid-19 pandemic, we must first briefly show the whole picture of ST\&I in Brazil, which includes introducing the Brazilian National System of Science, Technology, and Innovation (SNCTI), with its actors, priority areas and international cooperation strategies and partners.

Brazil's SNCTI is formed by government bodies in the federal, state, and municipal levels, educational and research institutions, funding agencies, innovative companies, and associations of academic, scientific, business, and union representation. Additionally, each group of actors has a function - for example, political actors such as MCTI and Confap are responsible for defining strategic guidelines for the system's initiatives. ${ }^{16}$ Meanwhile, funding agencies such as the CNPq, Capes, Embrapii and the Funding Agency for Studies and Projects (FINEP) allocate public resources through various instruments to support research, development, and innovation (R,D\&I) activities in order to enable the implementation of the guidelines agreed at the political level. Finally, operators of the system, including universities, technological parks, innovative companies, business incubators, and MCTI's research units, ${ }^{17}$ have the responsibility of executing the planned R,D\&I programs and projects (Brasil, 2016; Ipea and ABC, 2018).

The evolutionary path of SNCTI has been characterized by the need to pairing the country with the most sophisticated systems in the world since Brazil is still far from those advanced countries in terms of R\&D expenditure and human resources $^{18}$ (Brasil, 2016). In this sense, considerable investments have been carried out in recent years aiming at accelerating scientific and technological development, leading Brazil to stand out in several sectors of ST\&I (Brasil, 2016). In order to prove this argument, statistics on research and development $(\mathrm{R} \& D)$ in Brazil indicate a trend of steady

\footnotetext{
16. Other ministries also have important roles in SNCTI, some of which have departments and linked agencies responsible for managing ST\&I issues and R\&D funds. One pertinent example for the purposes of this paper is the MS and its Secretariat of Science, Technology and Strategic Inputs (SCTIE), responsible for the formulation and implementation of national policies of science, technology, and innovation for the health sector as well as the promotion of RD\&l in health (Brasil, 2016).

17. Research units under MCTI are: Atlantic Rainforest National Institute (INMT); Brazilian Center for Research in Energy and Materials (CNPEM); Brazilian Center for Research in Physics (CBPF); Brazilian Science and Technology Information Institute (IBICT); Center for Mineral Technology (CETEM); Emílio Goeldi Museum of the State of Para (MPEG); Museum of Astronomy and Related Sciences (MAST); National Astrophysics Laboratory (LNA); National Centre for Monitoring and Early Warnings of Natural Disasters (CEMADEN); National Institute for Amazonian Research (INPE); National Institute for Space Research (INPE); National Institute of Technology (INT); National Laboratory for Scientific Computing (LNCC); National Observatory (ON); Northeast Center of Strategic Technologies (CETENE); Renato Archer Information Technology Center - CTI; Semi Arid National Institute (INSA). Available at: <http://www.mctic.gov.br/mctic/opencms/institucional/paginas/Estrutura_Organizacional.htm>. 18. Total research and development personnel - researchers and supporting staff - accounted for 316.5 thousand people in 2014, equivalent to 3.4 per thousand total employment (Brasil, 2019).
} 
and consistent growth in R\&D investment in the period of 2000 to $2017,{ }^{19}$ when it increased from $\mathrm{R} \$ 12.5$ billion to $\mathrm{R} \$ 82.7$ billion. However, the resources invested in 2017 still corresponded to $1.26 \%$ of Brazilian GDP, far from the goal of $2 \%$ established by ENCTI to be pursued in the next years (Brasil, 2019; Marques, 2019). ${ }^{20}$

Despite this growth scenario, according to more recent information from the National Fund for Scientific and Technological Development (FNDCT) a significant portion of resources has been allocated as a contingency reserve in recent years. The total contingent resources in the period between 2006 and 2019 reached about $\mathrm{R} \$ 21$ billion, around 30\% of the R $\$ 70$ billion collected by the Sectoral Funds. ${ }^{21}$ In 2020, the budget proposed by the federal government and approved by the National Congress placed almost all the resources of the FNDCT in the contingency reserve - it was approved the use of only R \$ 600 million from the fund (De Negri and Koeller, 2020; SBPC, 2020).

Furthermore, even though Brazilian science has achieved relative prominence, as the country was the $13^{\text {th }}$ largest producer of research publications globally between 2011 and $2016,{ }^{22}$ when it comes to innovation indicators it is ranked in a relatively peripheral 66th position in the Global Innovation Index (GII) published in $2019^{23}$ (Brasil, 2019; Pasquali, 2019). Analysis point out that some elements capable of explaining the country's reduced capacity to generate results from innovation efforts include low levels of both public and private investments in $\mathrm{R} \& \mathrm{D}$, bureaucratic constraints to entrepreneurship, insufficient training and education of professionals, inadequate infrastructure conditions and political instability (Coutinho, Foss and Mouallem, 2017; CNI et al., 2018; Amon-Há et al., 2019). After understanding how the SNCTI works and general indicators on Brazil's ST\&I, it is necessary to understand the country's main goals and priority areas concerning ST\&I which can be found at the ENCTI 2016-2022 elaborated by MCTI. The priority areas involve aerospace and defense, water, food, biomes and bioeconomy, social sciences and technologies, climate, digital economy and society, energy, strategic minerals, nuclear, health, ${ }^{24}$ and converging and enabling technologies. This point is very important for our research considering the possibility of a comparison of this data with the areas of the cooperative initiatives collected in the next part of the article.

It is important to mention that the country considers international cooperation as an instrument to develop these areas. For example, the ENCTI 2016-2022 mentions that "fostering basic scientific

19. In 2016, it was observed a slight decline in R\&D expenditure, reduced to $R \$ 79.2$ billion, down from the amount of $R \$ 80.5$ billion in 2015, when Brazil reached a record high in R\&D spending as a percentage of GDP $-1.34 \%$. Brazilian GDP fell by 3.6\% in 2016, with the country suffering a deep recession, and the budgetary restrictions faced by the government compromised its ability to fund research projects at universities, research institutions, and innovative companies through funding agencies (Brasil, 2019; Marques, 2019).

20. In this paragraph, we consider total expenditures in $R \& D$, from both public and private sources.

21. Created since 1998, Sectoral Funds are instruments for financing research, development and innovation projects in Brazil. There are currently 16 Sectoral Funds in operation linked to FNDCT, fourteen of which destined to specific sectors: health, biotechnology, agribusiness, oil, energy, mineral, aeronautical, space, transportation, mineral, hydro, informatics, automotive and Legal Amazon. The other two are transversal funds, whose resources can be applied to projects in any sector of the economy, namely the Green-Yellow Fund, aimed at university-company interaction and the Infrastructure Fund, for supporting and improving the infrastructure of scientific, technological and innovation institutions (ICTs) (FINEP, s.d.; SBPC, 2020).

22. In the period between 2011 and 2016, Brazil accounted for 250,680 papers added to Web of Science and 364.803 papers indexed by the Scopus database (Brazil, 2019; Cross, Thomson and Sinclair, 2017; Marques, 2019).

23. In the period between 2011 and 2019, Brazil's global innovation highest ranking was 47th position in 2011 and its lowest ranking was the 70th position in 2015 (Pasquali, 2019).

24. The main goal with the Brazilian health sector in ST\&l is turned to the promotion of "science, technology, and innovation through basic, applied research and translational in health to strengthen the prevention, diagnosis and treatment of diseases chronic non-communicable diseases, and infectious diseases, as well as to reduce external dependence of products and technologies" (Brasil, 2016, p. 21). 
and applied research" involves "encouraging international cooperation with leading countries and institutions in strategic areas"; as well as the "modernization and expansion of the S,T\&I infrastructure" requires "strengthening and implementation of national multi-user centers and laboratories in strategic areas, including in cooperation with global R\&D centers"; and "training, attracting and maintaining human resources" covers the action of "encouraging international mobility programs [...] at masters and Ph.D. levels, particularly employing cooperative projects in strategic areas" (Brasil, 2016, p. 73-80).

According to MCTI, in the last two decades, Brazilian international cooperation in ST\&I has expanded whereas the country has gained even more prominence in the international scenario, in political, economic, social, and cultural terms. Currently, in addition to seeking to strengthen traditional cooperation with developed countries, Brazil has sought to boost partnerships with emerging nations, such as China and India bilaterally and within the scope of BRICS. In the regional context, efforts were made to support the process of political, economic, and social integration through cooperation with Argentina, Mercosur and Unasur. Brazil also sought to strengthen collaboration with African countries, both bilaterally and in the context of multilateral fora, such as the Community of Portuguese Speaking Countries (CPLP) and the Pro-Africa Program. ${ }^{25}$

In a pandemic scenario, as it was mentioned in the previous section, countries cooperate to find a solution that is related to ST\&I, and that is mainly related to health. Thus, it must be highlighted that Brazil is recognized by its Unified Health System (SUS) and that the country had regional and global protagonism when facing health emergencies such as HIV/AIDS, yellow fever, and the Zika virus (Brasil, 2018).

Therefore, considering the points presented above about the scenario of ST\&I development in Brazil, including the health sector, and the outlook on the Brazilian ST\&I international cooperation initiatives previous to the pandemic, it will be possible to better analyze Brazil's international cooperation initiatives in ST\&I in the context of the Covid-19 pandemic in the next section. Furthermore, it reinforces the importance of the actors investigated for this research.

\section{BRAZIL'S BILATERAL INTERNATIONAL COOPERATION IN ST\&I DURING COVID-19: AN OUTLOOK}

This section aims at analyzing Brazil's international cooperation in ST\&I in the context of the Covid-19 pandemic. As it was explained in the introduction, the authors made a systematization of all the bilateral international cooperation initiatives identified from January to July which resulted in a database with 53 initiatives (appendix). This systematization made it possible to draw some perceptions on how international cooperation in ST\&I in Brazil is being guided, which are the patterns of cooperation, the national actors involved as well as the main foreign partners and the areas that are being considered in the context.

First, when analyzing the name of the initiatives and the kind of instruments involved in each of them, it can be stated that there is a variety of initiatives and instruments that include delegations meetings, negotiations, missions, work plans, programs, and projects. The authors consider the importance of those initiatives since some of them can indicate the beginning of a relationship 
in ST\&I and because they may consider the establishment of bilateral instruments, opening new relationships, or deepening old ones. At the same time, in terms of Covid-19 cooperative relationships, it can indicate the recapture of former relations in other areas and its reorientation towards new issues and topics or to different patterns, for example, from technical cooperation to scientific and technological cooperation. The current cooperative relation with India which involved a Brazilian mission to the country is an example of new possibilities of ST\&I cooperation and shows the importance of this type of initiative and its alignment with the MCTI international cooperation strategies in ST\&I mentioned in the previous section. In the same way, the realization of the Fifth Meeting of the Brazil-U.S. Joint Commission on Science and Technology was a relevant event to deep old relations and also include Covid-19.

In chart 1 , it is possible to notice the national actors involved in the cooperative initiatives with attention to the most prominent ones.

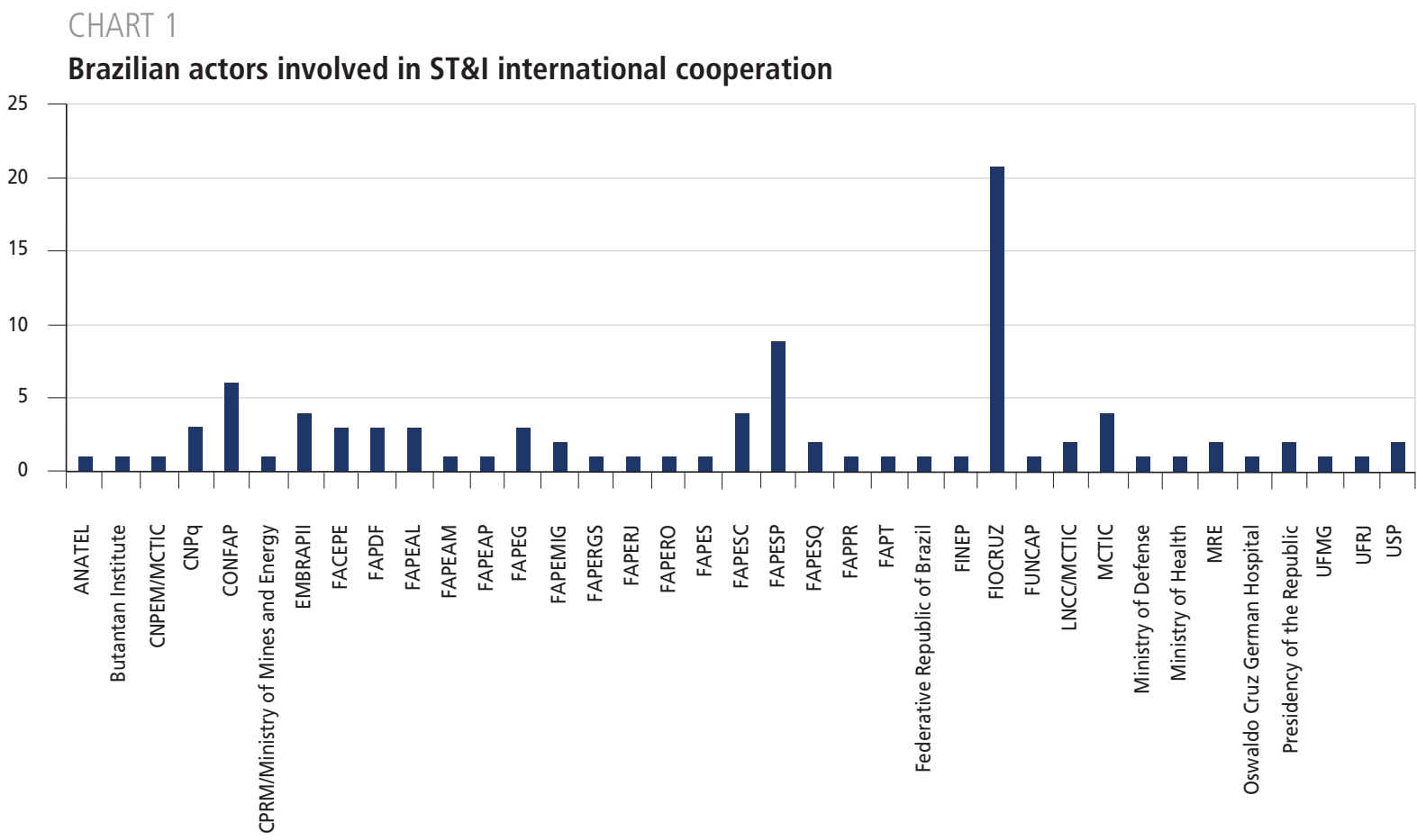

Authors' elaboration.

Fiocruz and Fapesp are the actors that appear more times in terms of initiatives. It is pertinent to mention the diversification of areas in which Fapesp develops international cooperation (appendix) with developed and developing countries and also including the Covid-19 pandemic. In the case of Fiocruz, especially because of the report received from the institution, we could see the relevant action in international cooperation in different topics around health issues and especially incorporating the theme Covid-19. Some other FAPs, Confap, Embrapii, MCTI, and CNPq should also be highlighted in comparison to the other institutions.

Complementing the analysis, chart 2 shows Brazil's international cooperation partners in this context. 
CHART 2

Partner countries in Brazilian ST\&I international cooperation

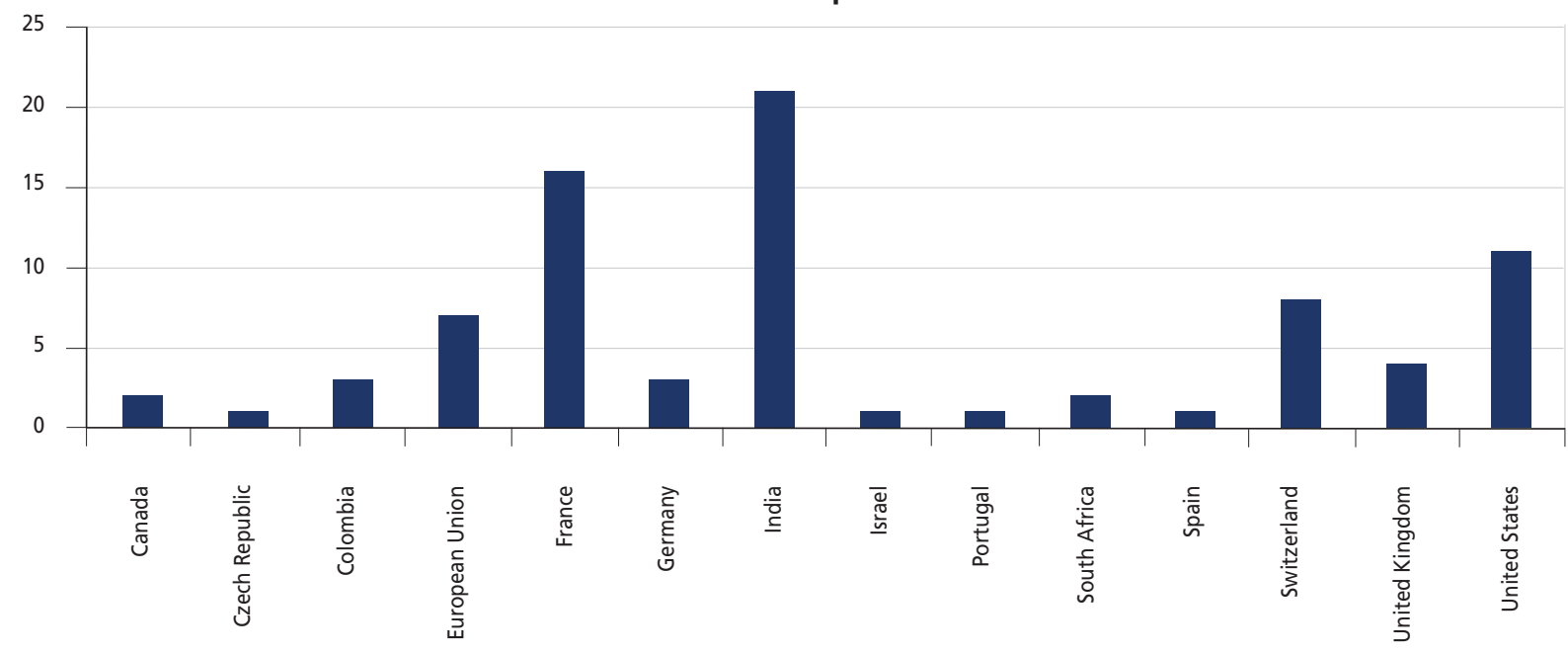

Authors' elaboration.

It can be seen through chart 2 that during the pandemic context, Brazil established cooperative initiatives with fifteen countries and the European Union. The ones with a higher number of cooperation initiatives were India, France and the United States, followed by Switzerland, the European Union, and the United Kingdom. Based on that, it is possible to state that Brazilian partners are mostly developed countries and, as a result, it consists of North-South Cooperation.

Furthermore, even though it was not possible to verify all the international initiatives content, it shows that Brazil usually has a more reactive action towards its partners in cooperation, especially when we observe many initiatives with the European Union linked to the European program of innovation named Horizon 2020. It means that in most cases it is the foreign actor that looks for Brazil as a partner, not the opposite. Even though it seems to be positive, it normally shows that Brazil does not know with whom it wants to cooperate and in which areas. As a result, there is a tendency of accepting the foreign partner's terms and having less bargaining power in negotiations especially considering North-South cooperation, which tends to be asymmetric. Finally, in chart 3, we analyze the areas of the bilateral instruments.

Through the chart, it is possible to see that most part of the areas involve solutions in ST\&I for the Covid-19 pandemic. In spite of that, cooperation in other areas was not neglected in this context, indeed, there is a broad range of areas and topics with predominance for Health, Particle Physics, and Innovation. Moreover, it is fundamental to mention that many areas are related to Brazil's strategic interests, as we can see through the analysis of ENCTI priority areas in part 4 of this article.

Also, it must be emphasized that despite this research considered only bilateral cooperation, there are several multilateral initiatives that Brazil is part of, such as the World Health Organization (WHO) Solidarity Clinical trials, the Covid-19 Clinical Research Coalition and, in the regional context, the development of regional strategies for fighting the pandemic among Mercosul member countries. 


\section{CHART 3}

\section{Areas of Brazilian ST\&I international cooperation}

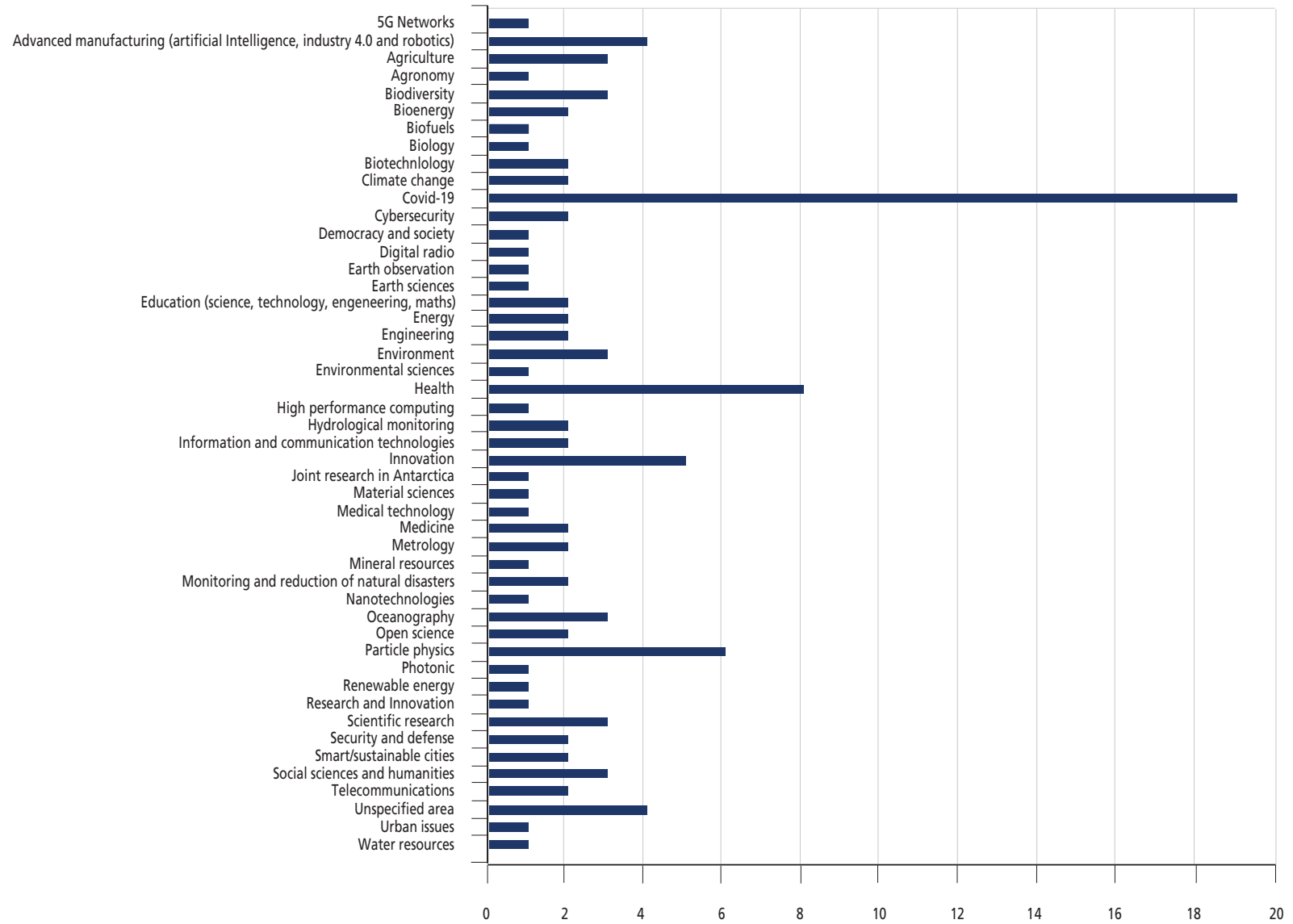

Authors' elaboration.

Moreover, when looking for information on the websites of the SNCTI actors, it was noticed that Brazil is developing several national initiatives oriented to find solutions to Covid-19 by developing treatments, medicines, and vaccines. It becomes clear in the list of clinical trials for medicines, treatments, and vaccines authorized until July 2020 by the National Health Surveillance Agency (ANVISA). The list includes also clinical trials developed by Brazilian private pharmaceutical companies and laboratories and the public Butantan Institute as well as the trials involving Brazil and foreign partners. ${ }^{26}$

Additionally, mapping the international cooperation initiatives involving the Brazilian SNCTI actors it was possible to see that there are also several national cooperation initiatives involving public calls for companies or researchers to develop scientific and technological solutions to Covid-19. The recognition of those initiatives is an important argument in favor of Brazilian Science, Technology, and Innovation capacities developed by the public, private and academic sectors especially in health, considering its experience in fighting previous epidemics and the importance of its public health care system, named SUS.

26. Available at: <http://portal.anvisa.gov.br/documents/33836/2492465/Ensaios+cl\%C3\%ADnicos+-+covid/9cda8d5c-5abd-4d65-819128ee7938e90a>. 


\section{FINAL REMARKS}

Since the declaration of the Covid-19 pandemic, international politics have been influenced by the dynamics of cooperation and competition involved in the countries' movements towards finding solutions to the disease. Since the answers for this issue involve ST\&I, and considering that the countries are not self-sufficient but interdependent in developing ST\&I capacities, cooperation could be noted as a tendency.

As Brazil is one of the several countries that are cooperating in ST\&I in this context, the authors found it important to identify and analyze closely its international cooperation initiatives to understand how the international cooperation in ST\&I have been conducted in the pandemic context, observing predominant areas, foreign partners, and national institutions involved. Based on this analysis, it could be identified that despite the unexpected context and all the new demands that it involves, as well as the public budget constraints, the country has been pursuing its national goals through relevant cooperative initiatives addressing issues regarded as strategic priorities for Brazilian development in ST\&I. We understand that the international cooperation agreements, meetings, missions, and projects considered in this research can strengthen existing partnerships and open windows of opportunity for mutual access to new experiences, technologies, and facilities in areas prioritized by Brazil's ST\&I policies and its different partner countries.

With the collected data, we found that Brazil's relations in ST\&I international cooperation is mainly with developed countries although there are initiatives with developing ones. This point reinforces the inequality behind ST\&I sphere and the general patterns of international cooperation in this scope. However, we could also find a quite relevant initiative with India, a developing country that has long been an opportunity for Brazil but whose possibilities in ST\&I were underexploited. Furthermore, it is relevant to mention that Brazil is considerably using bilateral and multilateral international cooperation in ST\&I for the development of shared knowledge about Covid-19 together with important domestic cooperation among its national institutions.

Gathering data for this research was a difficult process, especially because the information about Brazilian ST\&I cooperation is fragmented into different institutions. Despite Brazil's notable efforts to provide digital versions of official documents concerning international cooperation and ST\&I, as well as the possibility to require information of Brazilian ST\&I institutions to collaborate with academic researches, further progress is needed in Brazil in terms of organization and access to information.

We expect that this overview of Brazilian ST\&I international cooperation in the context of the Covid-19 may contribute to the existing knowledge on international cooperation in ST\&I and a better understanding of issues on the ST\&I agenda in Brazil. The information on recent developments and perspectives envisaged for international cooperation in ST\&I provided by this research may also be useful for the indication of paths in Brazilian national and international policies related to ST\&I.

\section{REFERENCES}

AMON-HÁ, R. et al. Índice de Inovação Global: uma análise da trajetória brasileira entre os anos de 2007 a 2018. In: MEETING OF THE NATIONAL ASSOCIATION OF GRADUATE CENTERS IN ECONOMICS (ENCONTRO NACIONAL DE ECONOMIA), 47., 2019, São Paulo. Anais... São Paulo: ANPEC, 2019. Available at: <https://www.anpec.org.br/encontro/2019/submissao/files_I/i9-30bba0c8bcf2 bb63bb77c7321c333b7f.pdf>. Accessed on: 27 Jul 2020. 
BRASIL. Ministério da Ciência, Tecnologia, Inovaçôes e Comunicaçôes. Estratégia nacional de ciência, tecnologia e inovação 2016-2022. Brasília: MCTIC, 2016.

Ministério da Saúde, Assessoria de Assuntos Internacionais de Saúde. Saúde e política externa: os 20 anos da Assessoria de Assuntos Internacionais de Saúde (1998-2018). Brasília: Ministério da Saúde, 2018.

Ministério da Ciência, Tecnologia, Inovaçóes e Comunicaçóes. Indicadores nacionais de ciência, tecnologia e inovaçáo. Brasília: MCTIC, 2019. Available at: <http://www.mctic.gov.br/mctic/export/sites/ institucional/indicadores/arquivos/Indicadores_CTI_2019.pdf>. Accessed on: 22 Jul 2020.

CHESBROUGH, H. To recover faster from Covid-19, open up: Managerial implications from an open innovation perspective. Industrial Marketing Management, v. 88, p. 410-413, Jul 2020.

CNI - CONFEDERAÇÃO NACIONAL DA INDÚSTRIA et al. Desempenho do Brasil no Índice Global de Inovaçáo 2011-2018. Brasília: CNI, 2018.

COUTINHO, D. R.; FOSS, M. C.; MOUALLEM, P. S. B. (Orgs.) Inovaçáo no Brasil: avanços e desafios jurídicos e institucionais. São Paulo: Blucher, 2017.

CROSS, D.; THOMSON, S.; SINCLAIR, A. Research in Brazil: a report for CAPES by Clarivate Analytics. [s. 1.]: Clarivate Analytics, 2017. Available at: <http://www.sibi.usp.br/wp-content/uploads/2018/01/ Relat\%C3\%B3rio-Clarivate-Capes-InCites-Brasil-2018.pdf>. Accessed on: 21 Jul 2020.

DAVIDSON, H. First Covid-19 case happened in November, China government records show - report. The Guardian, 13 Mar 2020. Available at: <https://www.theguardian.com/world/2020/mar/13/first-covid-19case-happened-in-november-china-government-records-show-report>. Accessed on: 27 Jul 2020.

DE NEGRI, F.; KOELLER, P. Políticas públicas para pesquisa e inovação em face da crise da Covid-19. Brasília: Ipea, 2020. (Nota Técnica, n. 64).

DE NEGRI, F.; MÁXIMO, G.; GOMES, F. G. O futuro da política tecnológica e de inovação no Brasil: caminhos para o pós-pandemia. Ipea, 2020. (Webinar).

FINEP - FINANCIADORA DE ESTUDOS E PROJETOS. O que sáo fundos setoriais. Finep, [s. d.]. Available at: < http://www.finep.gov.br/a-finep-externo/fndct/estrutura-orcamentaria/o-que-sao-os-fundossetoriais>. Accessed on: 28 Jul 2020.

FRY, C. et al. Consolidation in a crisis: patterns of international collaboration in Covid-19 Research. SSRN Electronic Journal, Jan 2020. Available at: <https://papers.ssrn.com/sol3/papers.cfm?abstract_id=3595455>. Accessed on: 27 Jul 2020.

HAVERTY; D.; PALMER; J.; KELLEY; L. Mapping the coronavirus outbreak. Foreign Policy, 4 Mar 2020. Available at: <https://foreignpolicy.com/2020/03/04/mapping-coronavirus-outbreak-infographic/>. Accessed on: 27 Jul 2020.

IPEA - INSTITUTO DE PESQUISA ECONÔMICA APLICADA; ABC - AGÊNCIA BRASILEIRA DE COOPERAÇÃO. Cooperaçáo brasileira para o desenvolvimento internacional: levantamento 2014-2016. Brasília: Ipea; ABC, 2018. Available at: <https://www.ipea.gov.br/portal/images/stories/PDFs/ livros/livros/181219_cobradi_2014-2016.pdf>. Accessed on: 20 Jul 2020.

JOHNS HOPKINS. Coronavirus Research Center. New cases of Covid-19 in world countries. Johns Hopkins, [s.d.]. Available at: <https://coronavirus.jhu.edu/data/new-cases>. Accessed on: 27 Jul 2020.

KEOHANE, R. O.; NYE, J. S. Power and interdependence in the information age. Foreign Affairs, n. 77, p. 81, Sep/Oct 1998.

KRIGE, J. Technological collaboration and nuclear proliferation: a transnational approach. In: MAYER, M.; CARPES, M.; KNOBLICH, R. (Eds). The global politics of science and technology. London: Springer, 2014. 
KRIGE, J.; KAI-HENRIK, B. Science, technology, and international affairs. Osiris, v. 21, n. 1, p. 1-21, 2006. MALLAPATY, S. Scientists' worlds will shrink in the wake of the pandemic. Nature, 4 Jun 2020. Available at: <https:/www.nature.com/articles/d41586-020-01523-1>. Accessed on: 27 Jul 2020.

MARQUES, F. Ciclo interrompido. Pesquisa FAPESP, n. 275, Jan 2019. Available at: <https://revistapesquisa. fapesp.br/en/2019/06/26/changing-trend/>. Accessed on: 21 Jul 2020.

MASCARELLO, J. International Cooperation in Science, Technology and Innovation in the context of the global Covid-19 pandemic. Mundorama, 28 Apr 2020. Available at: <https://mundorama.net/?p=27071 >. Accessed on: 29 Jul 2020.

MÜLLER, A.; SCHMITZ, S.; JOSTEN, M. Which thematic and regional approaches of science diplomacy exist? S4D4C European Science Diplomacy Online Course: module 5. Vienna: S4D4C, 2020.

PASQUALI, M. Global Innovation Index (GII) score of Brazil from 2011 to 2019. Statista, 11 Oct 2019. Available at: <https://www.statista.com/statistics/1055969/brazil-global-innovation-index-score/>. Accessed on: 22 Jul 2020.

ROEHRL, R. A.; LIU, W.; MUKHERJEE, S. The Covid-19 pandemic: a wake-up call for better cooperation at the science-policy-society interface. UN/DESA Policy Brief, n. 62, 22 Apr 2020.

SARAIVA, I. Z.; OLIVEIRA, N. S. M. N.; MOREJON, C. F. M. Impactos das políticas de quarentena da pandemia Covid-19, Sars-Cov-2, sobre a CT\&I brasileira: prospectando cenários pós-crise epidêmica. Cadernos de Prospecçáo, Salvador, v. 13, n. 2, p. 378-396, Apr 2020.

SBPC - SOCIEDADE BRASILEIRA PARA O PROGRESSO DA CIÊNCIA. Cientistas pedem liberação total do FNDCT. SBPC, 8 Jul 2020. Available at: <http://portal.sbpcnet.org.br/noticias/cientistaspedemliberacaototal-do-fndct/>. Accessed on: 28 Jul 2020.

SKOLNIKOFF, E. B. The Elusive Transformation: Science, Technology and The Evolution of International Politics. Princeton, New Jersey: Princeton University Press, 1993.

WAGNER, C. S. International collaboration in science and technology: promises and pitfalls. In: BOX, L.; ENGELHARD, R. (Eds.). Science and Technology Policy for Development, Dialogues at the Interface. London: Anthem Press, 2006.

WEN, J. et al. Many brains are better than one: the importance of interdisciplinary studies on Covid-19 in and beyond tourism. Tourism Recreation Research, 2020.

YOUNG, M. Building Better Science Diplomacy for Global Challenges: insights from the Covid-19 crisis. S4D4C Policy Brief, 18 Jun 2020. Available at: <https:/www.s4d4c.eu/policy-brief-building-better-sciencediplomacy-for-global-challenges-insights-from-the-covid-19-crisis/>. Accessed on: 28 Jul 2020. 


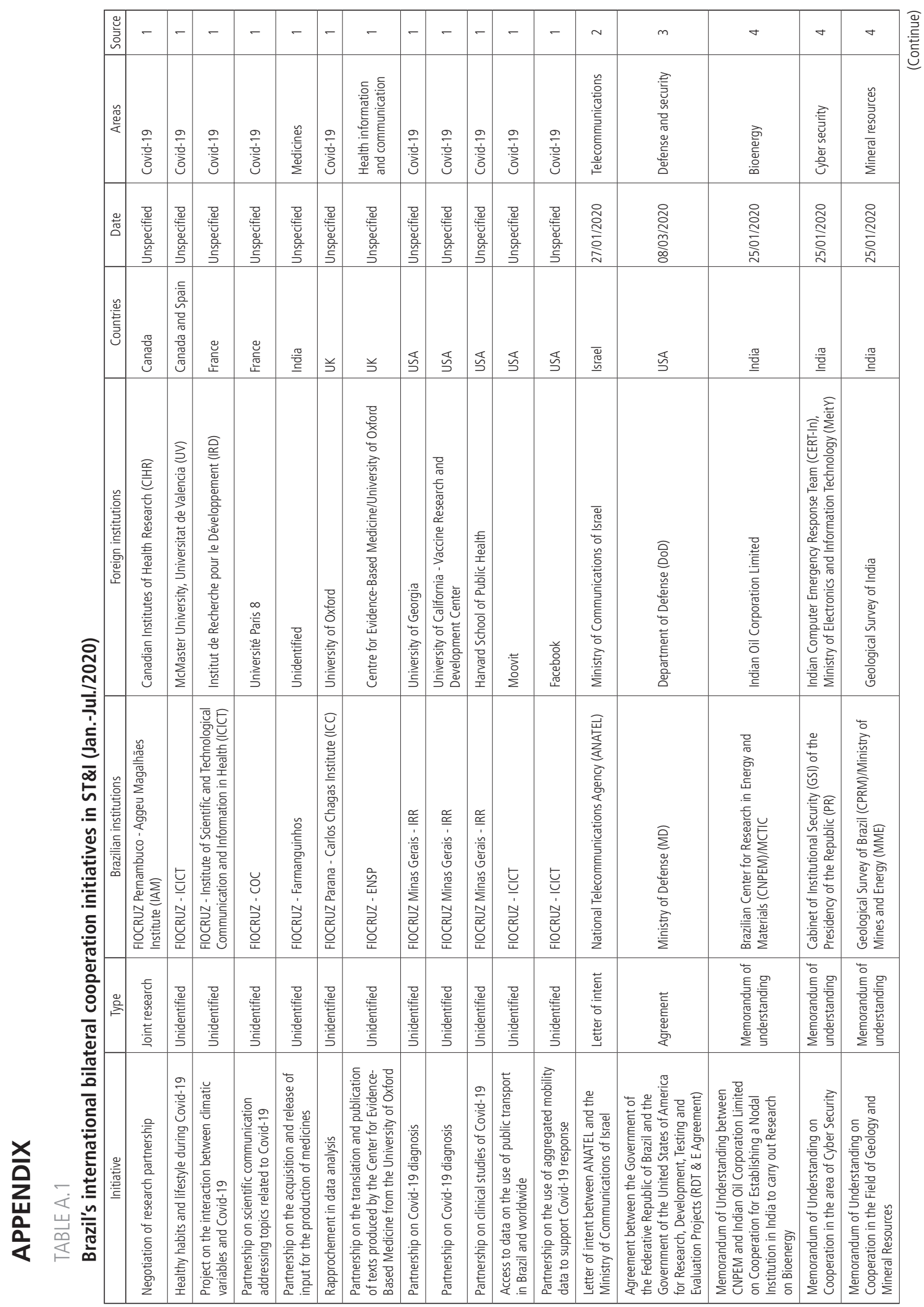




\begin{tabular}{|c|c|c|c|c|c|c|}
\hline 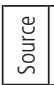 & in & 0 & $r$ & $\infty$ & $a$ & $a$ \\
\hline 旁 & 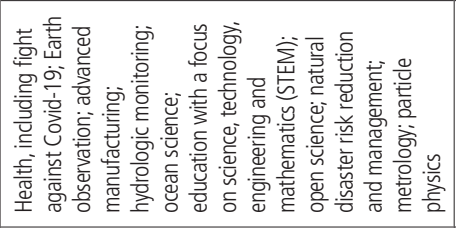 & 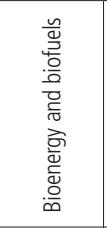 & 产 & $\frac{0}{\bar{c}}$ & 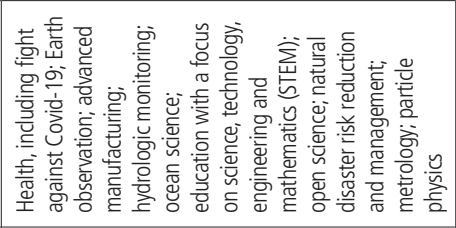 & 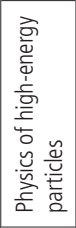 \\
\hline $\begin{array}{l}\text { 离 } \\
\text { to }\end{array}$ & 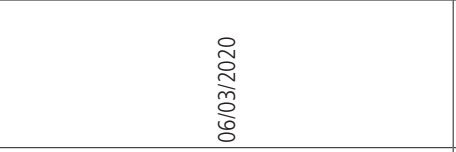 & 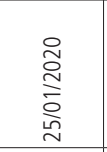 & 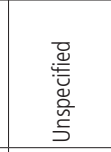 & 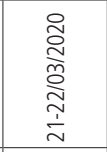 & 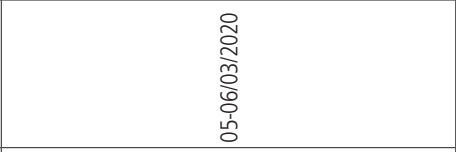 & 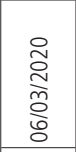 \\
\hline 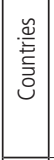 & 吕 & 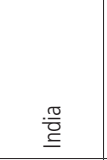 & 兰 & 兰 & $\stackrel{\mathbb{I}}{\mathrm{S}}$ & 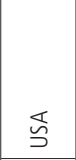 \\
\hline 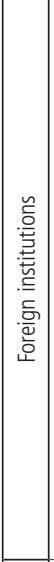 & 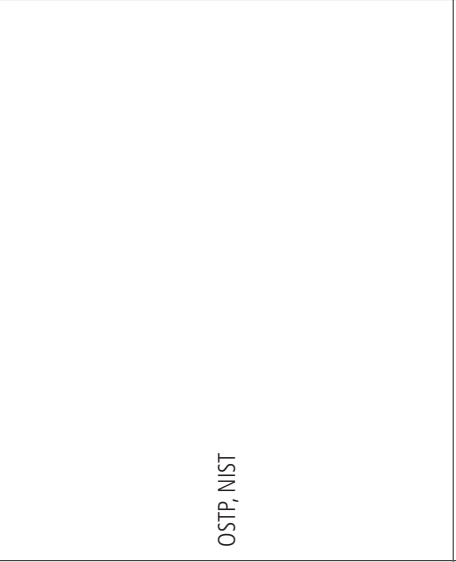 & 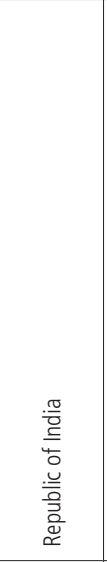 & 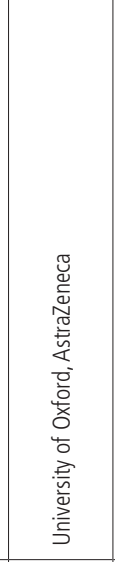 & 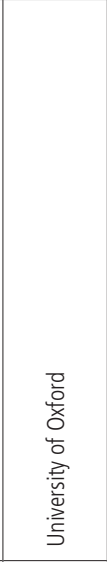 & 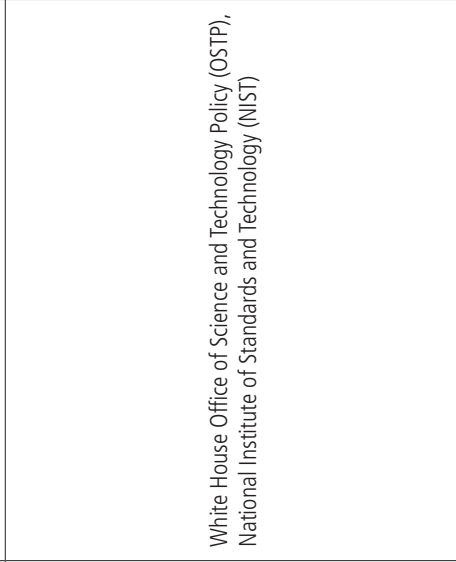 & 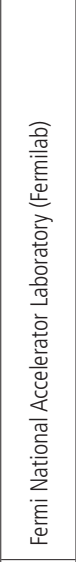 \\
\hline 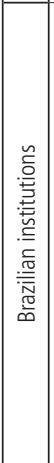 & 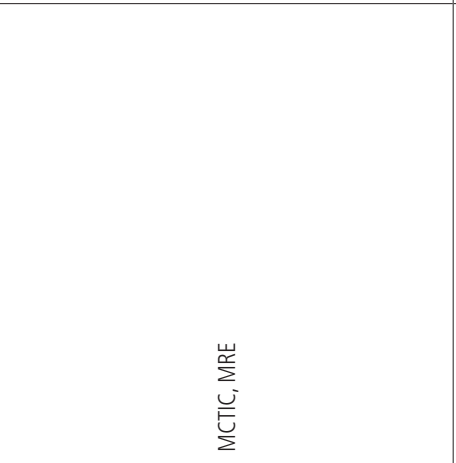 & 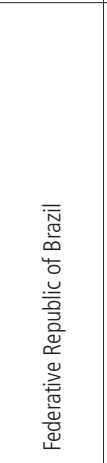 & 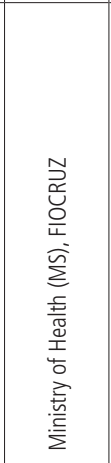 & 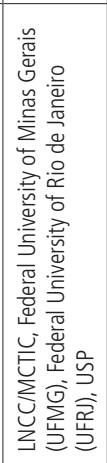 & 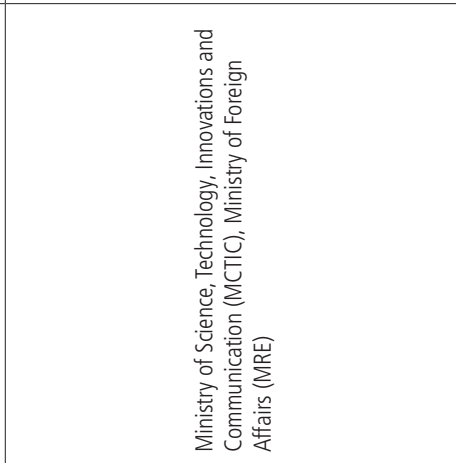 & 产 \\
\hline 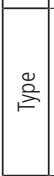 & 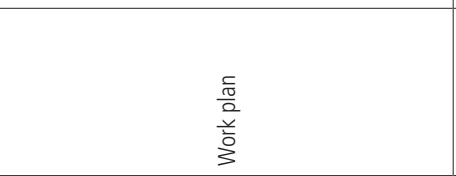 & 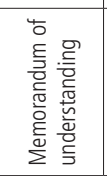 & 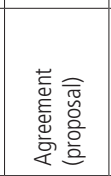 & 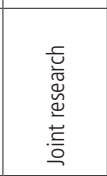 & 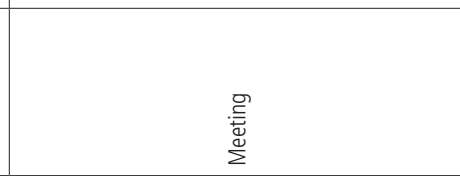 & 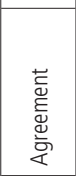 \\
\hline 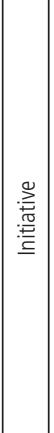 & 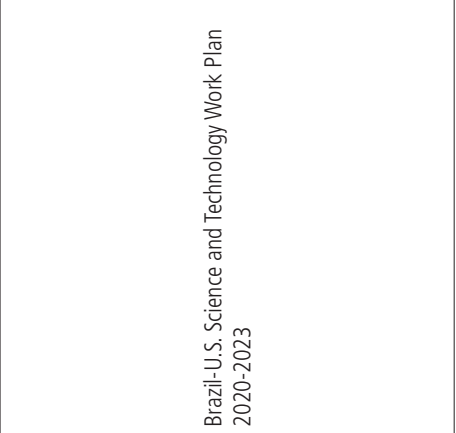 & 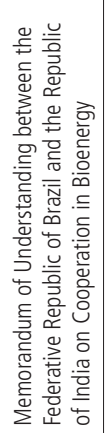 & 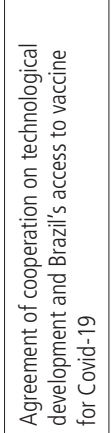 & 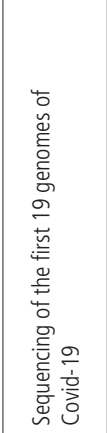 & 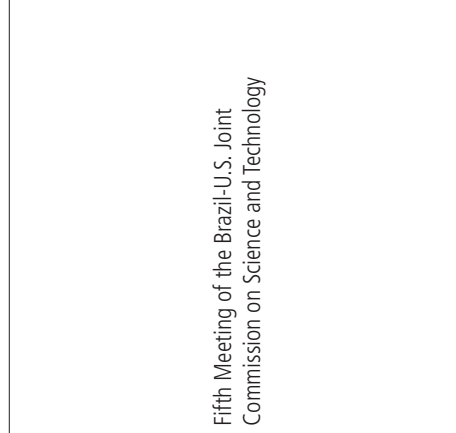 & 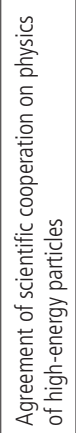 \\
\hline
\end{tabular}




\begin{tabular}{|c|c|c|c|c|c|c|c|}
\hline 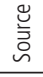 & 은 & $\therefore$ & $=$ & $\simeq$ & $m$ & \pm & $\stackrel{\Perp}{\llcorner}$ \\
\hline 嵌 & 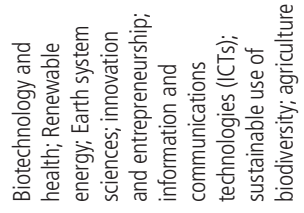 & 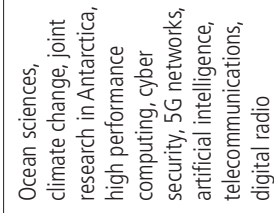 & 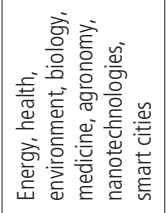 & 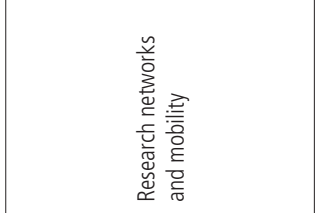 & 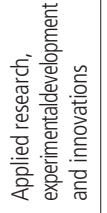 & 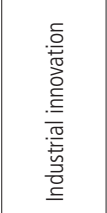 & 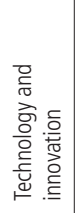 \\
\hline 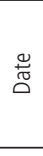 & 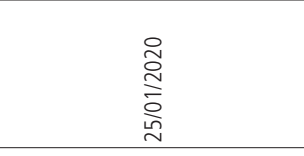 & 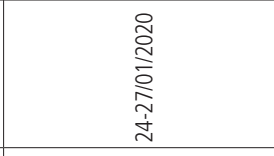 & 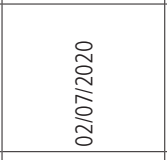 & తి & 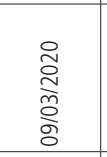 & 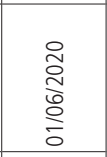 & 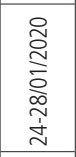 \\
\hline 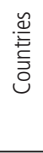 & 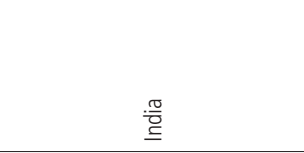 & 告 & 总 & 马 & 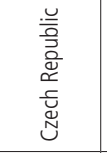 & J & $\underline{\underline{\underline{\underline{\sigma}}}}$ \\
\hline 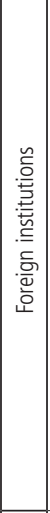 & $\frac{5}{\Sigma}$ & 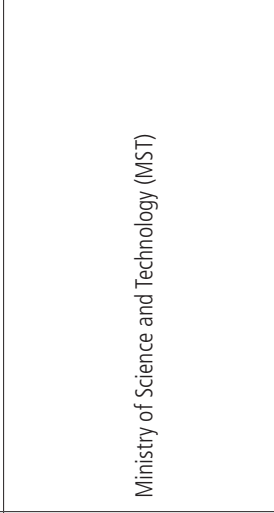 & 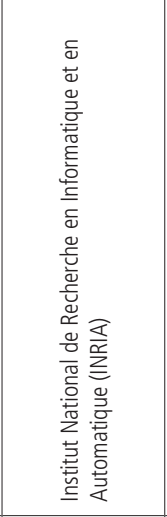 & 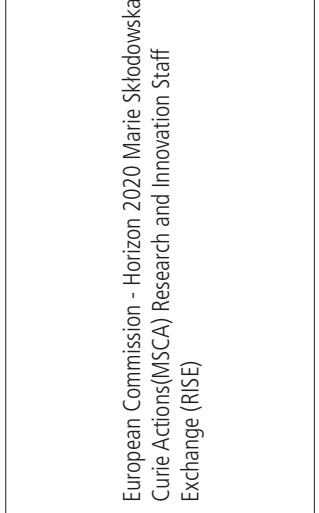 & 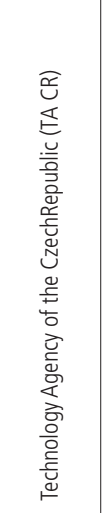 & 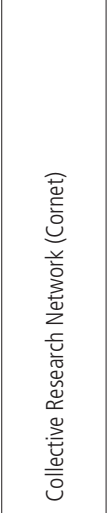 & 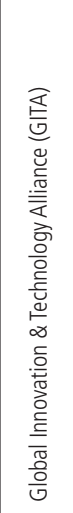 \\
\hline 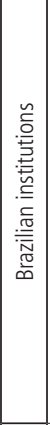 & $\stackrel{U}{\underline{E}}$ & 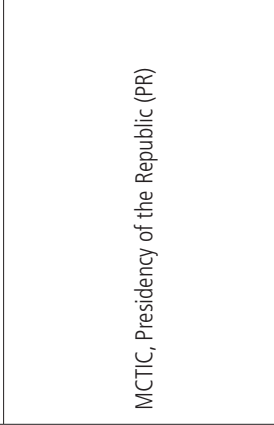 & 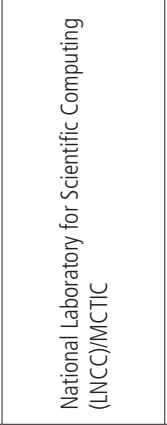 & 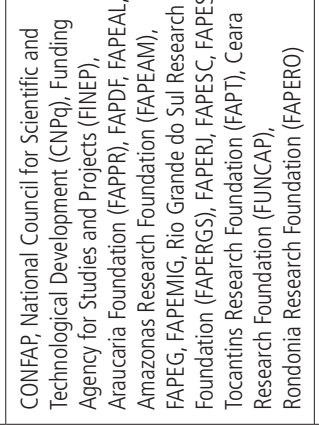 & 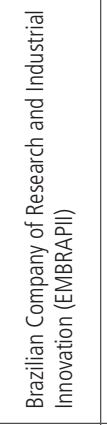 & 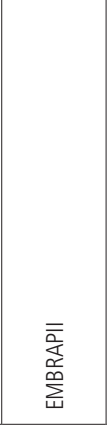 & $\begin{array}{l}\overline{\overline{\bar{c}}} \\
\text { 蔏 } \\
\sum_{\mathrm{w}}\end{array}$ \\
\hline$\stackrel{2}{\stackrel{2}{z}}$ & 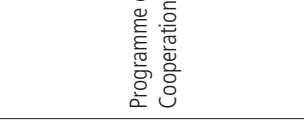 & 悥 & 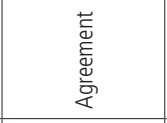 & $\begin{array}{l}\overline{\overline{\mathrm{s}}} \\
\text { 䓂 } \\
\end{array}$ & 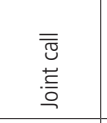 & $\begin{array}{l}\overline{\bar{T}} \\
\text { 产 } \\
\end{array}$ & 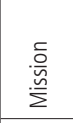 \\
\hline 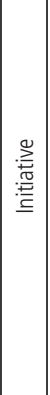 & 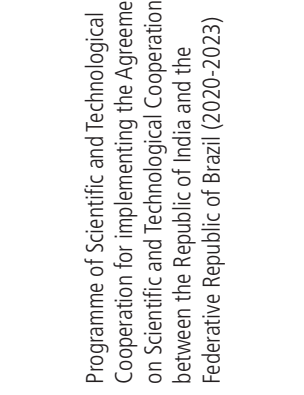 & 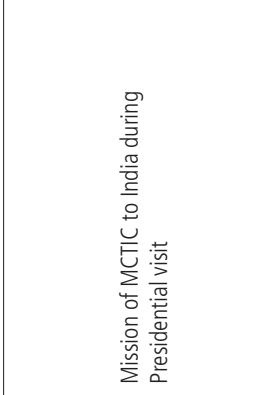 & 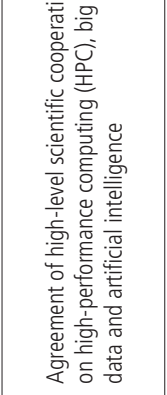 & 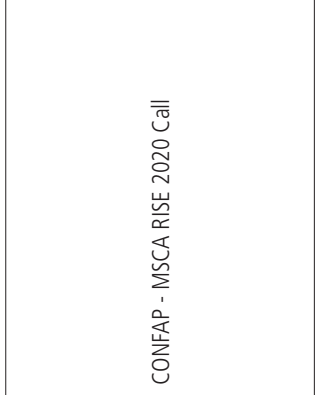 & 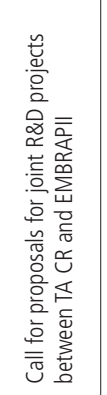 & 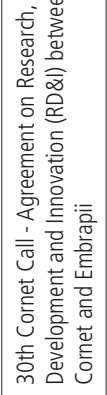 & 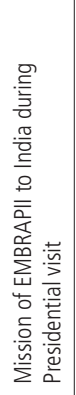 \\
\hline
\end{tabular}




\begin{tabular}{|c|c|c|c|c|c|c|c|c|c|c|c|c|}
\hline 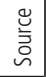 & $\simeq$ & $=$ & $\stackrel{\infty}{ }$ & $\stackrel{9}{ }$ & i & $\bar{\sim}$ & $\approx$ & $\approx$ & $\stackrel{d}{d}$ & $\stackrel{\sim}{\sim}$ & $\stackrel{\circ}{\sim}$ & $\bar{\lambda}$ \\
\hline 苞 & 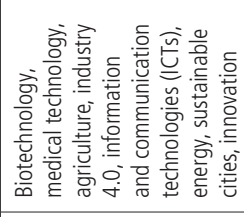 & 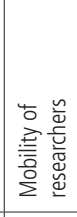 & $\begin{array}{l}\frac{9}{0} \\
\frac{\bar{c}}{0}\end{array}$ & 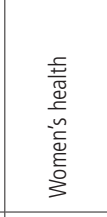 & 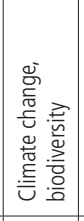 & 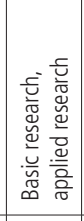 & 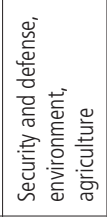 & 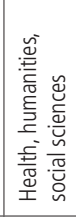 & 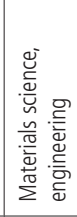 & 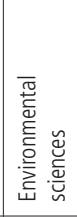 & 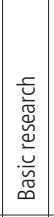 & 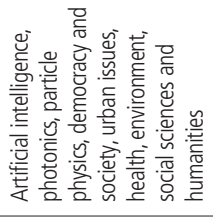 \\
\hline 受 & ఏ్తి & $\begin{array}{l}\stackrel{\Xi}{~} \\
\stackrel{\Xi}{0} \\
\stackrel{0}{0}\end{array}$ & 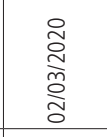 & 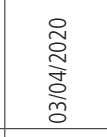 & 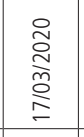 & $\begin{array}{l}\text { 今े } \\
\text { İ } \\
\text { ò }\end{array}$ & 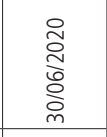 & 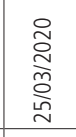 & 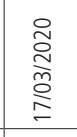 & $\begin{array}{l}\text { 今ิ } \\
\text { §ิ } \\
\text { ָू }\end{array}$ & 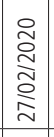 & 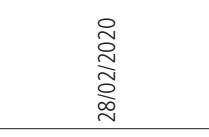 \\
\hline 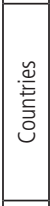 & 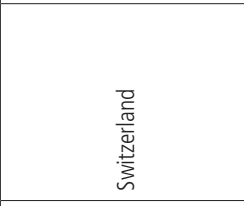 & 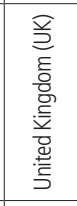 & 己 & 岁 & $\mathrm{u}$ & 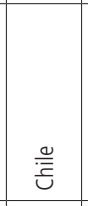 & 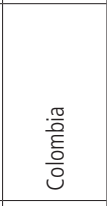 & $\begin{array}{l}\text { 总 } \\
\text { 䇏 } \\
\text { 音 }\end{array}$ & z & 兰 & 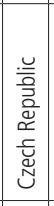 & $\begin{array}{l}\text { 总 } \\
\text { 焉 }\end{array}$ \\
\hline 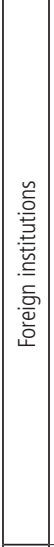 & 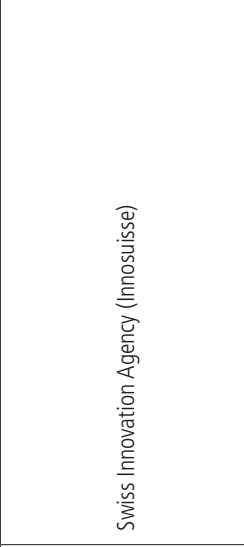 & 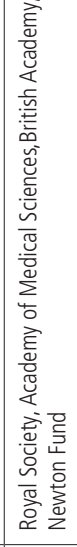 & 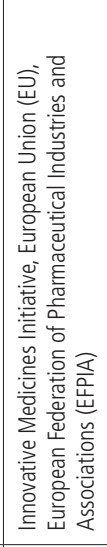 & 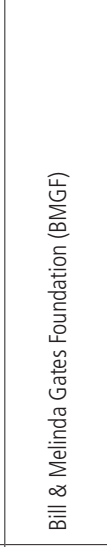 & 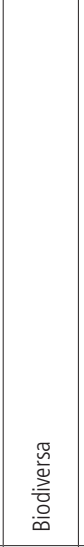 & 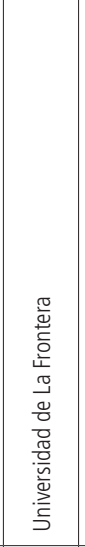 & 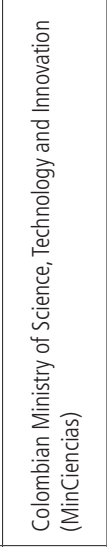 & 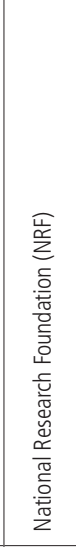 & $\begin{array}{l}\text { 崖 } \\
\text { 立 } \\
\text { 妾 }\end{array}$ & 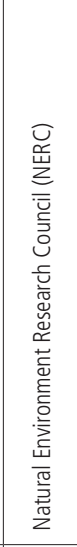 & 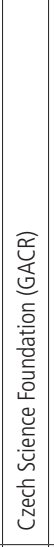 & 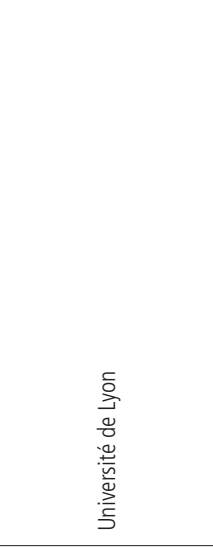 \\
\hline 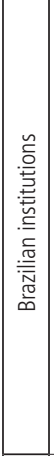 & 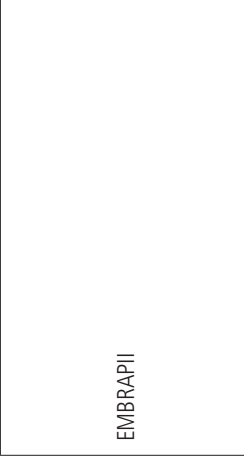 & 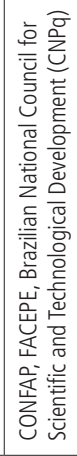 & 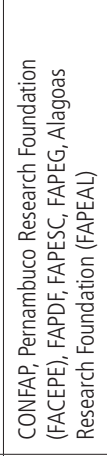 & 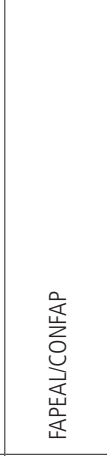 & 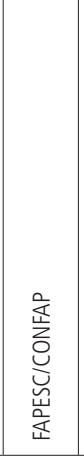 & 产 & 产 & 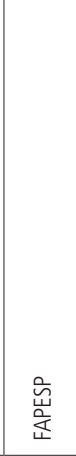 & 嵪 & $\begin{array}{l}\text { 产 } \\
\text { 㟧 }\end{array}$ & 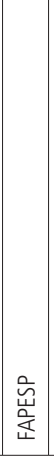 & $\begin{array}{l}\text { 产 } \\
\underline{\underline{u}}\end{array}$ \\
\hline$\stackrel{0}{2}$ & 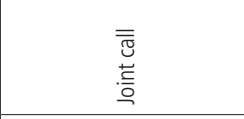 & 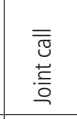 & $\begin{array}{l}\overline{\bar{J}} \\
\text { 豪 }\end{array}$ & 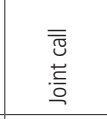 & 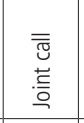 & 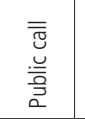 & 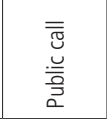 & 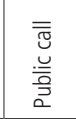 & 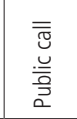 & 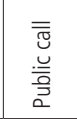 & 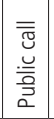 & $\begin{array}{l}\overline{\bar{c}} \\
\text { 害 } \\
\frac{a}{2}\end{array}$ \\
\hline 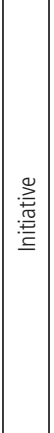 & 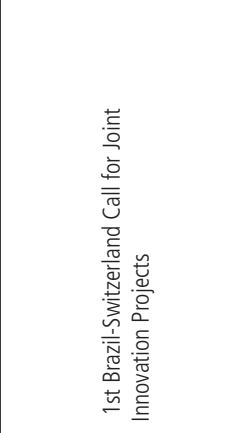 & 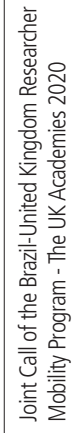 & 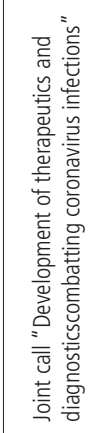 & 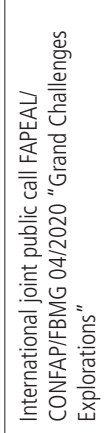 & 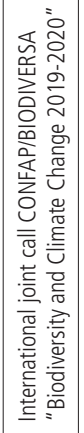 & 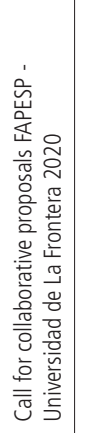 & 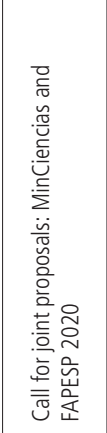 & 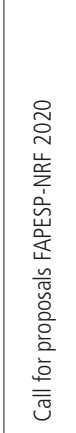 & 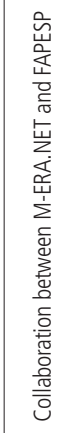 & 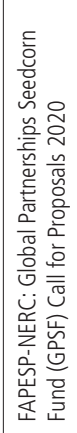 & 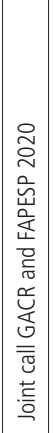 & 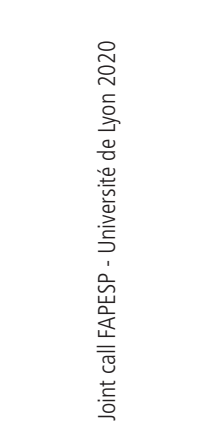 \\
\hline
\end{tabular}




\begin{tabular}{|c|c|c|c|c|c|c|c|c|c|c|c|c|}
\hline 总 & $\stackrel{\infty}{\sim}$ & $\stackrel{2}{2}$ & $\stackrel{\circ}{0}$ & $\bar{m}$ & $\bar{m}$ & $\tilde{m}$ & $\tilde{m}$ & $\tilde{m}$ & $\tilde{m}$ & $\stackrel{m}{m}$ & & \\
\hline 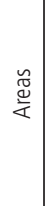 & 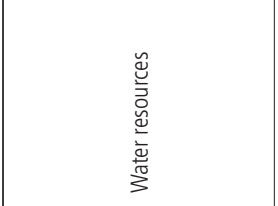 & 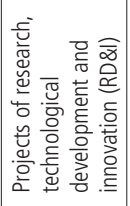 & $\frac{\stackrel{\circ}{\partial}}{\bar{c}}$ & 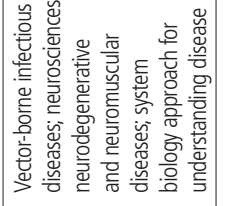 & 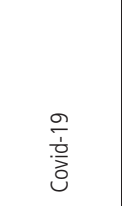 & 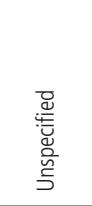 & 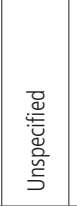 & 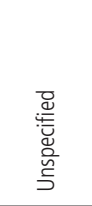 & 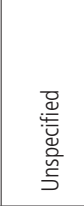 & 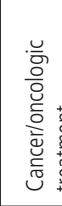 & & \\
\hline 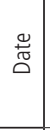 & 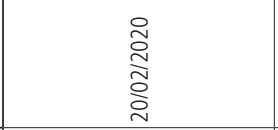 & 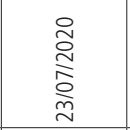 & 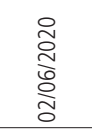 & 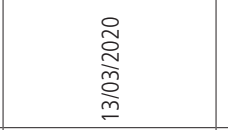 & రి & 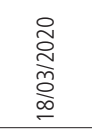 & $\begin{array}{l}\text { בे } \\
\stackrel{\tilde{N}}{0} \\
\text { Oे }\end{array}$ & 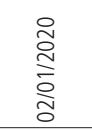 & 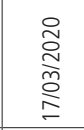 & 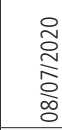 & & \\
\hline 总 & 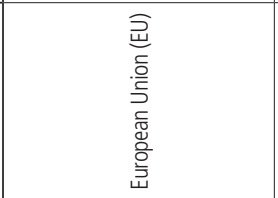 & 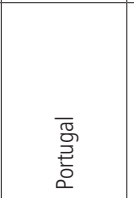 & 兰 & 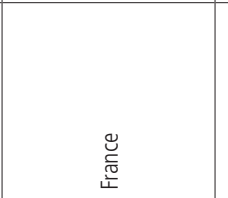 & 兰 & $\begin{array}{l}\text { 丞 } \\
\text { 핑 }\end{array}$ & 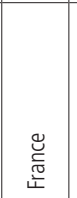 & 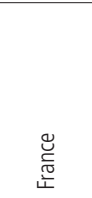 & 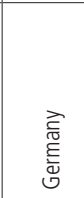 & $\begin{array}{l}\text { 总 } \\
\text { 童 }\end{array}$ & & \\
\hline 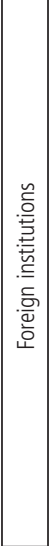 & 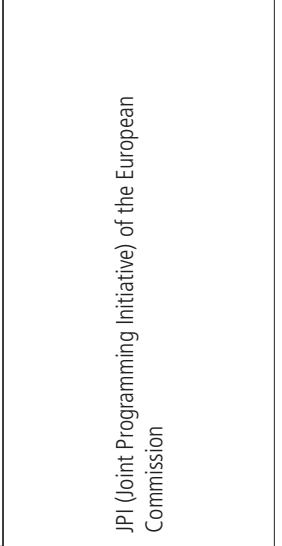 & 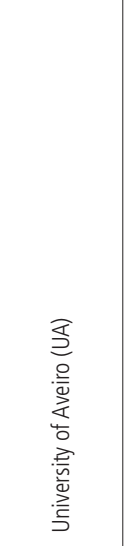 & 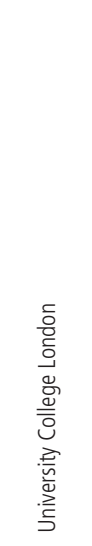 & 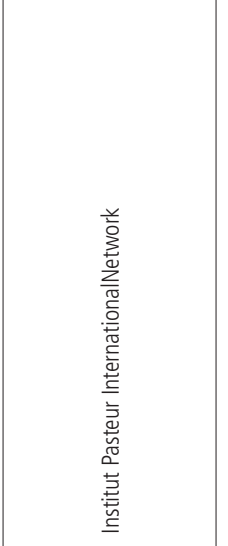 & 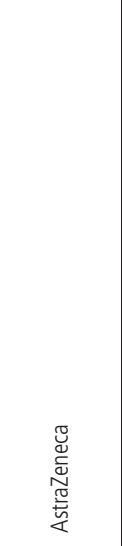 & 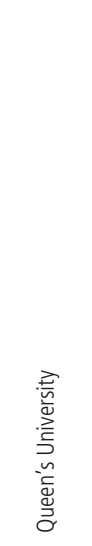 & 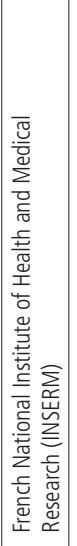 & 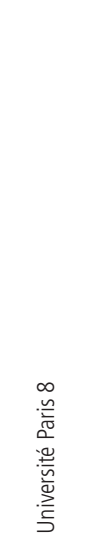 & 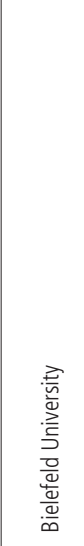 & 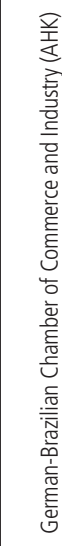 & & 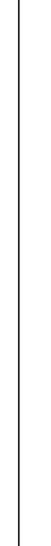 \\
\hline & 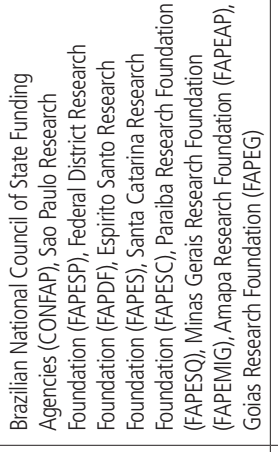 & 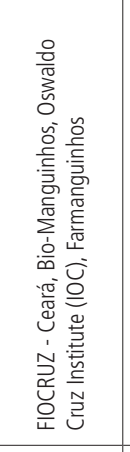 & 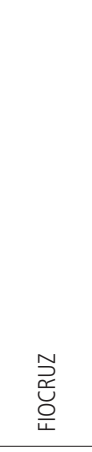 & 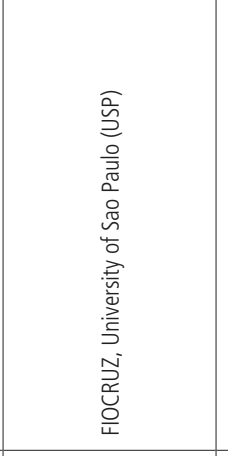 & 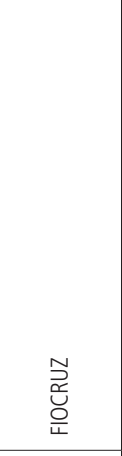 & 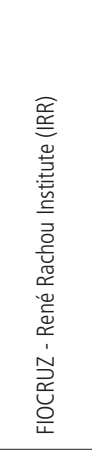 & 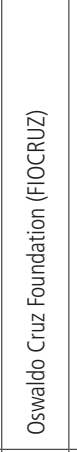 & 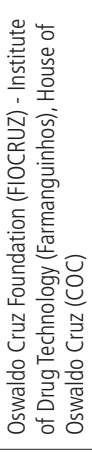 & 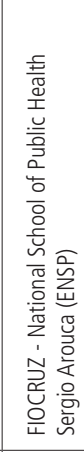 & 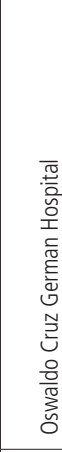 & & 更 \\
\hline$\stackrel{0}{\stackrel{0}{z}}$ & 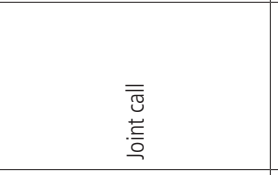 & 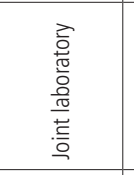 & 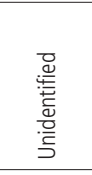 & $\begin{array}{l}\overline{\overline{\mathrm{J}}} \\
\stackrel{\underline{\overline{\bar{c}}}}{\mathrm{a}} \\
\end{array}$ & 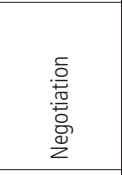 & 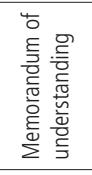 & 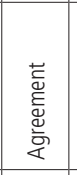 & 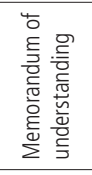 & 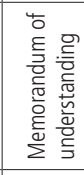 & 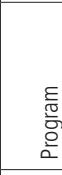 & & \\
\hline 恙 & 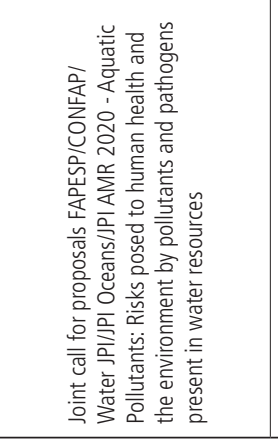 & 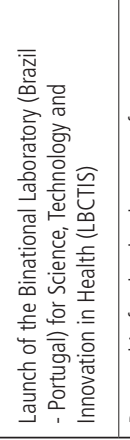 & 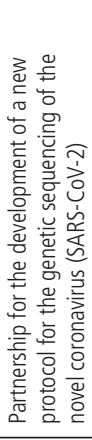 & 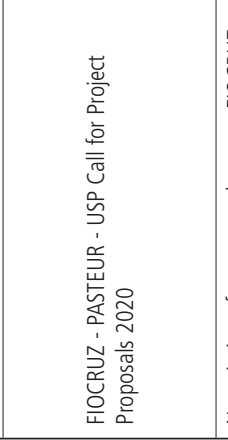 & 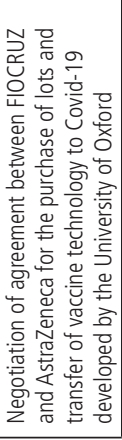 & 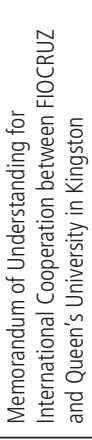 & 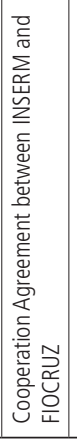 & 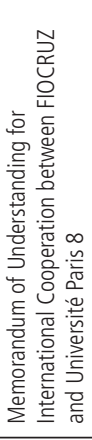 & 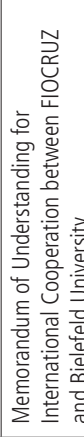 & 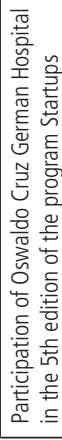 & & \\
\hline
\end{tabular}




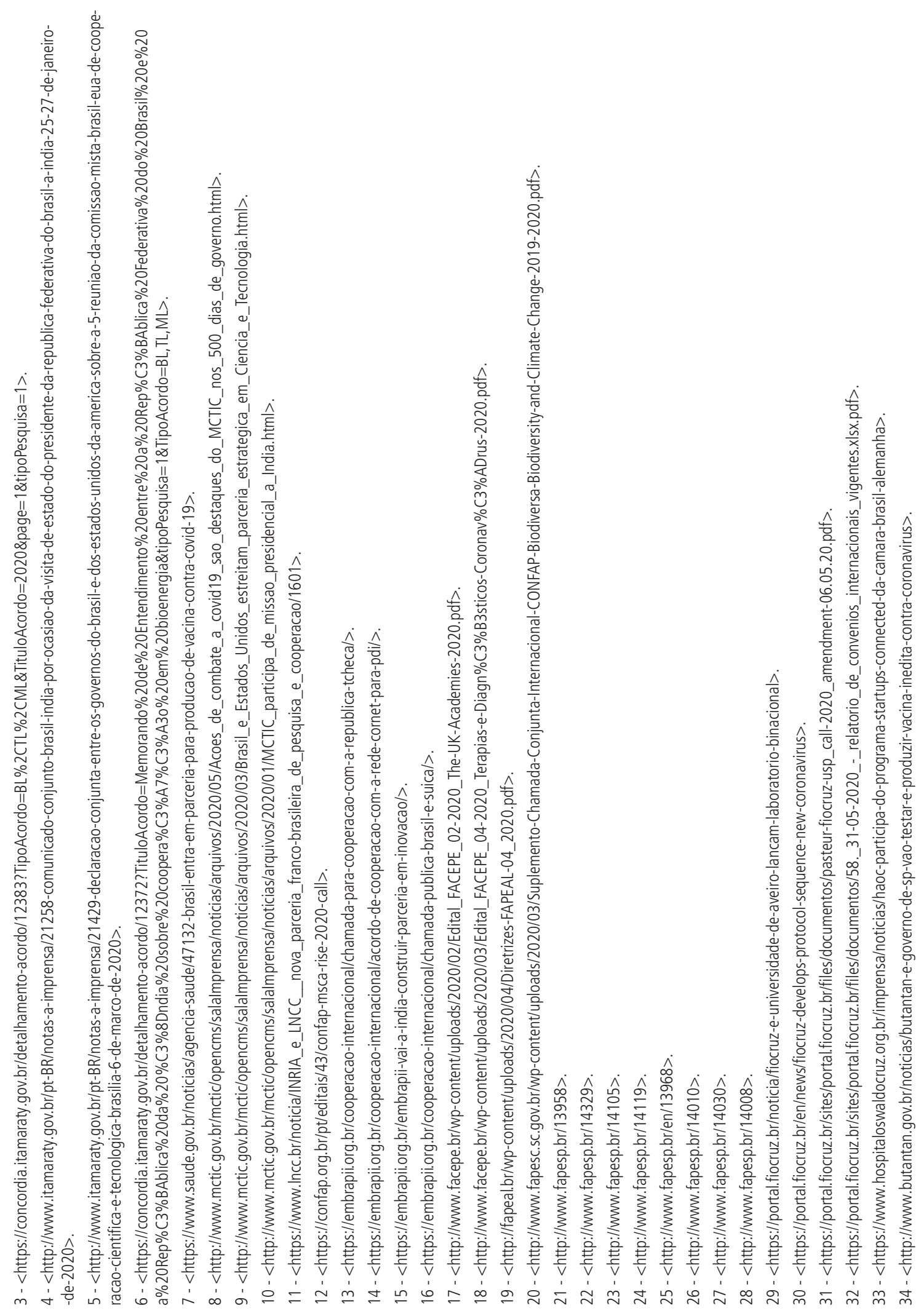

